\title{
Immunologic and Metabolic Biomarkers of $\beta$-Cell Destruction in the Diagnosis of Type 1 Diabetes
}

\author{
Jasmin Lebastchi and Kevan C. Herold \\ Department of Immunobiology and Internal Medicine, Yale University School of Medicine, New Haven, \\ Connecticut 06511 \\ Correspondence: Kevan.herold@yale.edu
}

Type 1 diabetes (T1D), also known as insulin-dependent diabetes mellitus, is a chronic disorder that results from autoimmune destruction of insulin-producing $\beta$ cells in the islets of Langerhans within the pancreas (Atkinson and Maclaren 1994). This disease becomes clinically apparent only after significant destruction of the $\beta$-cell mass, which reduces the ability to maintain glycemic control and metabolic function. In addition, it continues for years after clinical onset until, generally, there is complete destruction of insulin secretory capacity. Because prevention and therapy strategies are targeted to this pathologic process, it becomes imperative to have methods with which it can be monitored. This work discusses current research-based approaches to monitor the autoimmunity and metabolic function in T1D patients and their potential for widespread clinical application.

To pe 1 Diabetes (T1D) is the most severe type of diabetes, leading to lifelong dependency on daily insulin injections. This autoimmune disorder develops as a consequence of a synergistic combination of genetic predisposition, largely unknown environmental triggers, and immunologic events (Fig. 1). The clinical picture of T1D is a progressive loss of $\beta$-cell function over a period of years. The disease is a manifestation of an end-stage insulitis where only $10 \%-20 \%$ of the insulin-producing $\beta$ cell are estimated to still be functioning at the time of diagnosis. Once those cells are destroyed, patients with type 1 disease lose the ability to control the metabolism of blood glucose as well as fat and protein, which can result in metabolic decompensation. In addition, because of the inability of exogenous insulin administration to completely mimic physiologic insulin secretion and the failure of glucose counterregulation, patients are at risk for severe hypoglycemia as well as secondary complications such as kidney failure, blindness, and heart disease as a result of hyperglycemia and metabolic instability. To accelerate the development of therapies to prevent or even treat the disease, markers of the immunologic and metabolic processes that lead to the disease are needed (Fig. 1).

The incidence of T1D varies in different countries and population (Karvonen et al. 1993), which may reflect genetic as well as environmental differences. However, $\sim 90 \%$ of the

Editors: Jeffrey A. Bluestone, Mark A. Atkinson, and Peter R. Arvan

Additional Perspectives on Type 1 Diabetes available at www.perspectivesinmedicine.org

Copyright (C) 2012 Cold Spring Harbor Laboratory Press; all rights reserved; doi: 10.1101/cshperspect.a007708

Cite this article as Cold Spring Harb Perspect Med 2012;2:a007708 
J. Lebastchi and K.C. Herold

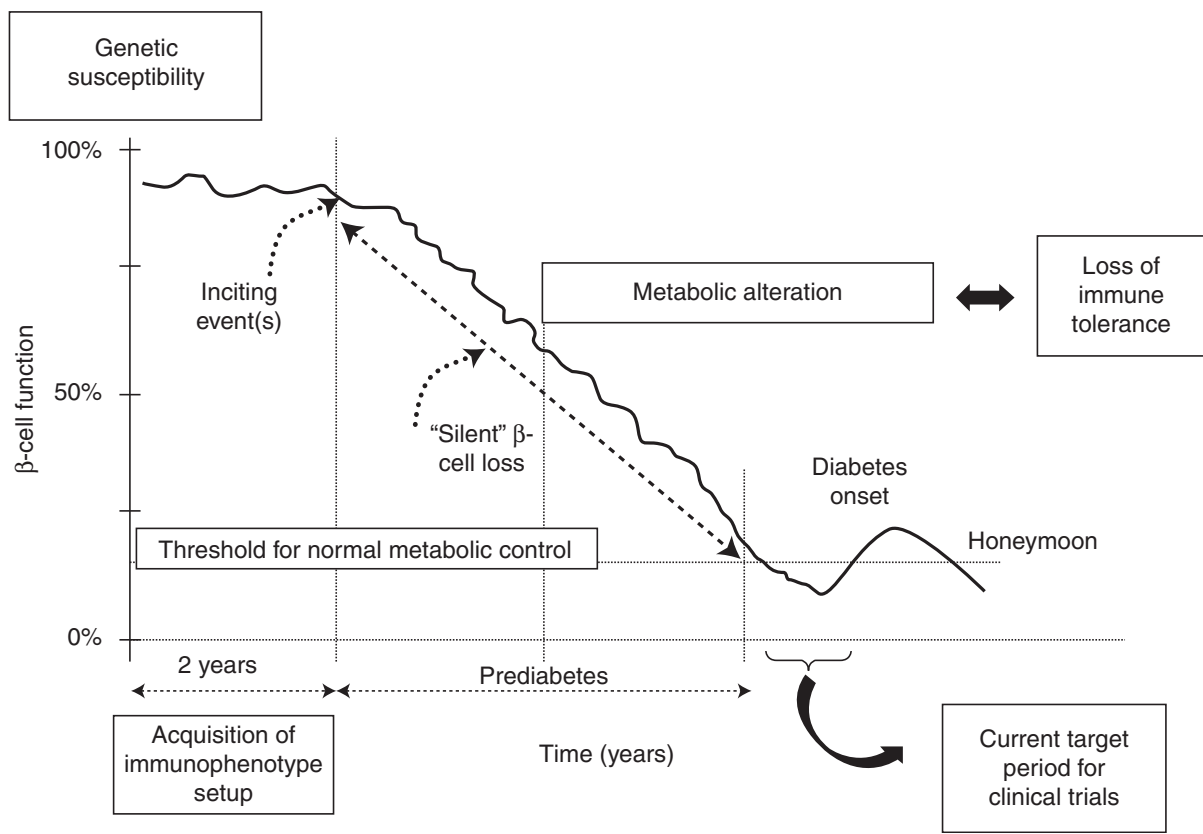

Figure 1. Natural history of type 1 diabetes: role of genetic, immunologic, and metabolic markers in defining the risk of the disease. This figure shows the relatively brief time period that is targeted by clinical trials. Improved predictive assays may identify individuals before significant $\beta$-cell destruction and metabolic impairment.

individuals with T1D develop the disease sporadically with no family history. Genetic susceptibility nonetheless plays a very important role, because the risk of developing T1D is $10-15$ times greater in people with a positive family history and the genes that are involved suggest immunologic pathways are involved. Because of their frequent occurrence in patients with the disease, many studies have examined the relationships between development of autoantibodies against islet antigens and the progression to disease. However, like the inheritance of associated genes, there is variability in the progression of disease among autoantibody-positive relatives of patients and these assays have not been widely tested in the general population. In addition, these markers of humoral immunity have not been useful in monitoring the efficacy of immune therapies. Clearly, a highly sensitive and specific biomarker that responds to an effective therapy would be very useful in monitoring clinical outcome, including the preservation of $\beta$-cell function. In this article, we will review immunologic and meta- bolic markers that have been used to characterize patients at risk and who have developed T1D and the changes in these markers with therapies.

\section{ISLET AUTOANTIBODIES}

Autoantibodies against pancreatic islet-cell antigens are commonly present during the preclinical period and diagnosis of T1D. These autoantibodies could be used as a marker of the ongoing autoimmune process to assess the efficacy of therapies. The most useful T1D markers are islet-cell autoantibodies (ICA) and autoantibodies against specific proteins including glutamic acid decarboxylase 2/GAD2/GAD65 (GADA), tyrosine phosphataselike molecules such as insulinoma-associated protein 2/IA-2/ ICA512/PTPRN (IA-2A), and IA-2B/PTPRN2 (IA-2BA), insulin (IAA), and the zinc transporter ZnT8/SLC30A8 (ZnT8A) (Table 1). Insulin and ZnT8 proteins are predominantly found in islet cells, whereas GAD65 and IA-2 are distributed in multiple tissues. 
Table 1. Main antibodies and targets used as a marker of the ongoing autoimmune process in type 1 diabetes

\begin{tabular}{ll}
\hline Antibodies & \multicolumn{1}{c}{ Targets } \\
\hline ICA & Islet cells \\
IAA & Insulin \\
GADA & Glutamic acid decarboxylase \\
IA-2A & Insulinoma-associated antigens 2 \\
IA-2ßA & \\
ZnT8A & Zinc transporter (ZnT8) \\
\hline
\end{tabular}

Results from Workshops to Evaluate Autoantibodies in Patients with T1D

In two workshops using blinded samples, autoantibodies could effectively distinguish patients with T1D from healthy control subjects. Sixtyone percent of subjects with type 1 diabetes were positive for two or more autoantibodies versus $0 \%$ of the control subjects. In those workshops (Seyfert-Margolis et al. 2006; Herold et al. 2009) that evaluated the sensitivity, specificity, and reproducibility of immunologic markers in T1D, the specificity for any single autoantibody ranged from $92 \%-99 \%$ (Herold et al. 2009) or $85 \%$ (Seyfert-Margolis et al. 2006). However, the sensitivity of autoantibody measurements was as low as $59 \%-67 \%$ when a single autoantibody was measured (Table 2). When any one of two autoantibodies (i.e., GADA and/or IA2A ) was present, the specificity improved. The reproducibility of autoantibody measurements was excellent $\mathrm{K}=0.70$ or $86 \%$ (Table 2 ).

Autoantibody measurements have been found to be very useful for prediction of T1D. In the Diabetes Prevention Trial (DPT-1) the combination of three or more autoantibodies increases the risk of diabetes $>50 \%$ after 5 years (Krischer et al. 2003). Interestingly, the DPT-1 data indicate that the number of autoantibodies, rather than the autoantibody specificity predicts T1D risk, whereas the particular type and titer of an autoantibody only partially influences disease prediction. In younger individuals, the risk approaches even $90 \%$ within 7 years (Orban et al. 2009).

\section{Effects of Immune Therapies on Autoantibodies}

Data from immune therapy trials have shown mixed changes in autoantibodies and responses to the therapy. The French and the CanadianEuropean cyclosporine A trial showed that response to treatment, determined by reduced requirements for exogenous insulin injection, did not correlate with GADA or other anti-islet autoantibodies (Stiller et al. 1984; Bougneres et al. 1988). In the initial anti-CD3 mAb trial, an association was not seen between the titer of GADA or IA-2A and response to drug treatment (Herold et al. 2002). In contrast, Rituximab

Table 2. Sensitivity, specificity, and reproducibility of the assay

\begin{tabular}{|c|c|c|c|c|}
\hline Assay & Sensitivity & Specificity & к $(95 \% \mathrm{Cl})$ & Comments \\
\hline $\begin{array}{l}\text { Autoantibodies } \\
\text { (one or more) }\end{array}$ & 83 & 92 & $0.70(0.58-0.82)$ & $\begin{array}{l}\text { Combination of three or more autoantibodies } \\
\text { increases the risk }\end{array}$ \\
\hline Anti-GAD65 & 68 & 98 & & \\
\hline Anti-ICA512 & 58 & 99 & & \\
\hline Anti-ICA & 59 & 94 & & \\
\hline $\begin{array}{l}\text { Cellular } \\
\text { immunoblot }\end{array}$ & 74 & 88 & $0.63(0.41-0.86)$ & $\begin{array}{l}\text { Requires fresh cells, large volumes, and } \\
\text { multiple antigens, not biased by HLA; } 18 \\
\text { antigenic blots }\end{array}$ \\
\hline $\begin{array}{l}\text { T-cell } \\
\text { proliferation }\end{array}$ & 60 & 69 & $0.52(0.30-0.73)$ & $\begin{array}{l}\text { Up to } 20 \text { antigens tested; requires fresh cells; } \\
\text { antigens can be grouped }\end{array}$ \\
\hline Class II tetramer & 46 & 72 & $0.41(0.15-0.68)$ & $\begin{array}{l}\text { HLA restriction; can be performed on frozen } \\
\text { cells; specificity useful for perspective study }\end{array}$ \\
\hline U.K.-ELISPOT & 61 & 69 & $0.08(-0.20-0.36)$ & $\begin{array}{l}\text { Optimally performed on frozen cells; HLA } \\
\text { restricted; eight antigens tested }\end{array}$ \\
\hline
\end{tabular}

Abbreviations: CI, confidence interval; HLA, human leukocyte antigen; ELISPOT, enzyme-linked immunosorbent spot. 
(anti-CD20 mAb) treatment affected the titers and prevalence of anti-insulin antibodies; both were decreased in drug-treated subjects in the TrialNet Rituximab trial (Yu et al. 2011). However, the anti-insulin antibodies that were seen in patients treated with exogenous insulin may not reflect the same pathogenic mechanism as those appearing in prediabetic subjects who have not been treated with insulin. Interestingly, the baseline titer of IAAs at study entry was markedly lower for patients who maintained C-peptide levels during the first year. This may indicate that the levels of IAA, independent from Rituximab treatment, may be associated with disease prognosis and progression. Rituximab did not have the same effect on other autoantibodies such as GADA, IA2A, and ZnT8A. Moreover, there was no correlation between IAA levels and C-peptide. Thus, further studies with other immune-modulating agents will be required to determine the relationship, if any, between autoantibody titers, responses to immune therapies, and clinical disease. In other Rituximab trials, patients with systemic lupus erythematosus showed a decrease in antinucleosome and anti-dsDNA antibodies but not to other autoantibodies or antimitochondrial antibodies. These investigators suggested that these differences indicate a more rapid turnover of the anti-dsDNA antibody-producing B cells such as the $\mathrm{V}_{\mathrm{H}} 4.24$ subpopulation. (Cambridge et al. 2006). The therapeutic effects of Rituximab and, in particular, how Rituximab reduces the titer of serum antibodies without altering the overall antibody titers are not clear. In a mouse model of inflammatory arthritis Huang et al. (2010) showed that Rituximab specifically targets short-lived autoreactive plasma cells, which expressed CD20 and have a rapid turnover.

\section{IDENTIFICATION OF AUTOREACTIVE T CELLS}

\section{Immunoblot}

Multicenter workshops to evaluate cellular immune responses in patients have shown that three assays can reliably distinguish responses in patients from control subjects with accept- able reproducibility: the cellular immunoblot, T-cell proliferation assay, and ELISPOT assay. The immunoblot assay, which measures T-cell proliferative responses to multiple islet antigens that have been separated by gel electrophoresis and transferred to nitrocellulose, has consistently shown its ability to distinguish responses in patients and healthy controls with blinded samples (Herold et al. 2009). It is not dependent on major histocompatibility complex (MHC) type. In addition, a positive immunoblot response was found before the diagnosis of disease and predicted disease onset in individuals at risk (Brooks-Worrell et al. 2001). Limitations of this assay include the requirements for relatively large numbers of peripheral blood mononuclear cell cultures (PBMC) and the need for fresh (i.e., not frozen) cells (Table 2). This creates a problem for prospective immune therapy trials, although the reproducibility of the assay in repeated samples from the same individual was good, $\mathrm{K}=0.63$ or $82 \%$ (Table 2 ). In addition, the antigens that are recognized are not clear and therefore, the responses to individual antigens may change even without a change in the blot score.

\section{T-Cell Proliferation Assay}

A similar but more defined approach has been the measurement of T-cell proliferation to known islet antigens. In this assay, which also requires the use of fresh cells, $\mathrm{T}$-cell proliferation to 11 different diabetes-associated antigens is measured in the presence of low concentrations of IL-2. The assay is based on the observation that the autoreactive $\mathrm{T}$ cells are found in patients but not controls and they require IL-2 to proliferate (Dosch et al. 1999). Like the immunoblot assay, these responses can be measured in all subjects with T1D, regardless of human leukocyte antigen (HLA) type. Antigens may be grouped into islet, neuronal, and milk antigens, which have been proposed as targets of T-cell responses in T1D patients. This assay also has shown good performance in two workshops with blinded samples from patients with new-onset disease and healthy control subjects (Table 2). Like the immunoblot assay, the T-cell 
proliferation assay is limited by the need for freshly isolated cells. Interestingly, like theimmunoblot as well as autoantibody measurement, a positive response to a high number of different specificities rather than the magnitude of responses to each was the best predictor of responses in patients.

The T-cell proliferation assay was recently used to evaluate cellular responses in the TrialNet Rituximab trial (Herold et al. 2011). Surprisingly, the indices were not significantly different in subjects treated with Rituximab and placebo during the first year of the trial. However, among the Rituximab treated group, clinical responders, identified by maintenance of C-peptide responses were distinguished from nonresponders by an increased T-cell proliferation score to islet and neuronal antigens. The enhanced responses clearly indicate that the drug treatment did not deplete antigen-specific $\mathrm{T}$ cells. However, the reason for the increased response, e.g., changes in cytokines by autoreactive $\mathrm{T}$ cells, has not been studied.

\section{ELISPOT}

Enzyme-linked immunosorbent spot assays have been used to identify cytokine responses to T1D-associated antigens. In these assays, antigenic peptides are used to stimulate IL-10 or IFN $\gamma$ production and the number of cytokinepositive spots provides an indirect assessment of the frequency of antigen-specific T cells and the cytokines that they produce. Because of the selected peptides, the assay is currently limited to use in patients who are HLA-DR4. Importantly, cytokine production to diabetes-associated antigens can be found in healthy control subjects. In patients with $\mathrm{T} 1 \mathrm{D}$, a bias toward IFN $\gamma$ production is seen, whereas in healthy control subjects, IL-10 production to the same antigens is characteristic (Arif et al. 2004). These responses have also been used to distinguish responses in T1D patients and control subjects but the reproducibility is not as strong as other assays. More recently, these investigators have expanded their analysis of cytokine responses to these antigens and have found increased IL-17 production in patients compared with healthy controls (Arif et al. 2011). They showed that peripheral blood $\mathrm{CD}^{+}{ }^{+} \mathrm{T}$ cells from newly developed type 1 diabetes secrete IL-17 in response to $\beta$-cell autoantigens. IL-17 is produced in inflamed islets and therefore might play a key role in $\beta$-cell death.

\section{MHC-Peptide Tetramers Staining}

Islet antigen-specific $\mathrm{CD}^{+}$and $\mathrm{CD}^{+}{ }^{+} \mathrm{T}$ cells can be identified by class I and II MHC tetramer staining. Tetramers consist of four linked MHC molecules with a bound peptide, and tagged with a fluorochrome. They identify $\mathrm{CD}^{+}{ }^{+}$and $\mathrm{CD}^{+} \mathrm{T}$ cells that are specific for that peptide expressed by the MHC molecule.

\section{Class II MHC Tetramers}

For identification of class II-restricted $\mathrm{CD} 4^{+} \mathrm{T}$ cells, the antigen-specific T cells from PBMC are first expanded with monomers or peptide plus IL-2 because the frequency of the cells has been below the detection limit for flow cytometers in cells from most patients. This assay is limited to particular HLA-DR types (e.g., HLA-A2.1, DR3, or 4) and specific antigens (e.g., IGRP [islet-specific glucose-6-phosphatase catalytic subunit-related protein], GAD65, proinsulin, and insulin peptides) but it can be performed with frozen cells (Table 2). The class II tetramer assay has shown excellent specificity and reasonable reproducibility but the sensitivity is not high. Thus, as a method for tracking antigen-specific $T$ cells in the setting of clinical trials, it may be very useful because assays using samples from multiple time points can be analyzed together. A potential problem with this approach is that the cells may be altered by expansion in vitro.

\section{Class I MHC Tetramers}

Standifer et al. (2006) and Ouyang et al. (2006) identified HLA-A0201 IAPP9-17, IGRP215-223, IGRP152-160, islet IA-2(172-180), and IA-2 (482490) and glial fibrillary acidic protein (GFAP), preproislet amyloid polypeptide ( ppIAPP), and IGRP that bind to HLA-A*0201 with a strong 
affinity and contain a COOH-terminal proteasomal cleavage site. These peptides induced granzyme $\mathrm{B}$ release by $\mathrm{CD}^{+} \mathrm{T}$ cells in an ELISPOT assay and discriminated responses in patients with T1D compared with healthy control subjects.

Class I MHC tetramers have been used to identify reemergence of auto versus alloimmunity in patients with T1D who received islet allografts (Pinkse et al. 2005). Pinske et al. found that cells reactive with an insulin $B$ chain peptide (ins $\mathrm{B}_{10-18}$ ), identified by tetramer staining correlated with graft failure. In addition, Coppieters et al. (2011) used class I MHCspecific tetramers to identify antigen-specific $\mathrm{T}$ cells in the islets of individuals with T1D and insulitis at the time of death. This method has the advantage of enumerating the cells without expansion in vitro, which may change the relative as well as the absolute number of antigenspecific T cells, but has significant technical limitations. First, the frequency of the cells is very low. Even viral antigen-specific $\mathrm{CD}^{+} \mathrm{T}$ cells, for which the precursor frequency is relatively high, are found at a frequency $1 \%$ or less in the peripheral blood. In addition, positive controls for the cell measurements are not available because clonal populations of the antigen-specific $\mathrm{CD}^{+} \mathrm{T}$ cells have not been isolated. To circumvent these problems with specificity of class I tetramers, Velthuis et al. have developed Qdots to detect antigen-specific $\mathrm{CD}^{+}{ }^{+} \mathrm{T}$ cells in PBMC. By using multidimensional encoded MHC multimers, background staining is significantly reduced compared with staining with tetramers. They identified HLA-A2-restricted insulin $\mathrm{B}_{10-18}$, preproinsulin $(\mathrm{PPI})_{15-24}$, islet antigen (IA)-2 $297-805$, GAD65 $114-123$, islet-specific glucose-6-phosphatase catalytic subunitrelated protein (IGRP) $265-273$, and preproislet amyloid polypeptide (ppIAPP $)_{5-13}$-specific $\mathrm{CD}^{+} \mathrm{T}$ cells in recent-onset diabetic patients, their siblings, healthy control subjects, and isletcell transplantation recipients (Velthuis et al. 2010).

Class I MHC tetramers are now being used in a number of clinical and therapeutic settings. Velthuis et al. (2010) found that the frequency of T1D antigen-specific T cells identified with class I MHC tetramers declined following treatment of islet allograft recipients with antithymocyte globulin. The presence of the diabetes antigen-specific $\mathrm{CD} 8^{+} \mathrm{T}$ cells was correlated with clinical outcome: The presence of the antigenspecific cells predicted failure to obtain insulin independence in 6-7 recipients. Cernea and Herold (2010) used class I HLA-0201 tetramers to identify GAD65, proinsulin, insulin, and IGRP-specific $\mathrm{CD}^{+} \mathrm{T}$ cells in patients with T1D. In subjects treated with teplizumab (antiCD3 $\mathrm{mAb}$ ) the frequency of GAD65 andi Bpeptide-reactive $\mathrm{CD}^{+}{ }^{+} \mathrm{T}$ cells was increased after $\mathrm{mAb}$ treatment. This analysis is consistent with the notion that the anti-CD3 mAb works through mechanisms other than simply depletion. Assays that measured cytokines showed elevated serum CXCL1 in acute-onset T1D subjects (Takahashi et al.2011) and elevated levels of IL-6, IL-16, and $\alpha$-TNF, and chemokine IL-8 before the development of T1D in children in the presence of autoantibodies (Zak et al. 2010).

Interestingly, levels of certain circulating cytokines (IL-18 increased, MIF and MCP-1 decreased) and chemokines could show a strong association with islet autoantibody status (IA$2 \mathrm{~A}$ and GADA) in patients with recent-onset T1D (Hanifi-Moghaddam et al. 2003).

\section{METABOLIC MARKERS}

\section{C-Peptide Response and Insulin Secretion}

The use of C-peptide has arisen as a means to directly assess destruction of $\beta$ cells by autoimmune attack. Its clinical significance is based on findings, largely from the Diabetes Control and Complications Trial (DCCT) that retention of endogenous insulin production of at least $0.2 \mathrm{pmol} / \mathrm{mL}$ is associated with improved glucose control and a reduced risk of certain secondary end-organ complications such as eye and kidney disease and even a reduced rate of severe hypoglycemia (Palmer et al. 2004). The latter may be attributable to both improved glucagon responses and ability to extinguish insulin secretion in response to insulin-induced hypoglycemia. Endogenous insulin secretion is most frequently assessed by measurement of 
stimulated C-peptide responses. C-peptide, with a plasma half-life of $\sim 30 \mathrm{~min}$, is a by-product of the enzymatic reaction of proinsulin to insulin and is released exclusively by insulin-producing $\beta$ cells in the islets of Langerhans. Standardized measurements following stimulation of C-peptide secretion with glucose, a mixed meal, or arginine provide the most sensitive and clinically validated method to evaluate $\beta$ cell function. Although all three stimuli have been used in clinical trials, stimulation with a mixed meal is the most physiologic and combines glucose-dependent and glucose-independent (amino acid) stimulation of insulin secretion (Greenbaum et al. 2004). The mixed-meal tolerance test (MMTT) stimulus produced significantly higher concentrations of C-peptide than the glucagon stimulation test (Greenbaum et al. 2004). Both tests were highly reproducible, but the MMTT was significantly more so $\left(R^{2}=\right.$ 0.96 for peak C-peptide response). Subjects generally prefer a MMTT because of nausea that may be associated with the arginine infusion.

Some trials have reported results using a fasting C-peptide level or the peak response to provocation. These approaches, although generally correlated with total secretory responses, do not evaluate the full dynamic capacity of $\beta$ cells. There is proportionally a greater decrease in stimulated versus basal C-peptide responses with progression of the disease. Therefore, measurements of basal or fasting values alone lack the sensitivity of the responses to dynamic testing.

There have been relatively few studies that have prospectively evaluated the changes in Cpeptide response from prediabetes, to diagnosis, and in the years following until C-peptide responses are no longer detectable. Studies by Tsai et al. (2006) and Sosenko et al. (2008), using data from the DPT- 1 effort have identified a progressive decline in $\mathrm{C}$-peptide responses that are relatively modest during the prediabetic period compared with the changes after diagnosis with hyperglycemia. Interpretation of the changes in C-peptide responses may be more complicated in children because there is an age-related increase in C-peptide levels and therefore, the absence of an increase may be equivalent to a decline in response (Sosenko et al. 2006, 2008; Tsai et al. 2006).

After the onset of disease, the decline over time appears to be more dramatic. In the DCCT, only $2.8 \%$ of subjects diagnosed with T1D under the age of 18 had clinically significant Cpeptide response (defined as a stimulated value of at least $0.2 \mathrm{pmol} / \mathrm{mL}$ ) 5 years after diagnosis. However, individuals with a stimulated C-peptide value of $>0.5 \mathrm{pmol} / \mathrm{mL}$ were specifically excluded from the DCCT, so these findings may underestimate the prevalence of significant insulin production with longer duration. Steele et al. (2004) reported an average decline of 756 $\pm 132 \mathrm{pmol} / \mathrm{mo}$ in the C-peptide response to a mixed meal, to a final value of $28 \pm 8.4 \%$ of initial levels 2 years after diagnosis. These studies, which are now more than a decade old, should be replicated with contemporary data because it is clear that glucose control may affect the decline in $\beta$-cell function. In addition, age may again be a factor in determining the rate of decline in C-peptide. Recent analysis of the natural history of $\beta$-cell decline in control subjects in TrialNet studies suggests that the rate of decline in C-peptide is consistent until the age of 21 but then is significantly less (Greenbaum et al. 2012).

\section{OTHER METABOLIC MARKERS}

Apart from glucose and insulin secretion, other metabolic markers may be useful in humans for identifying progression of the immunologic disease. Oresic et al. (2008) found changes in the serum metabolome in children who later progressed to T1D. In their prospective study they analyzed the metabolite profiles of 56 children who progressed to T1D and 73 controls who did not progress and remained permanently autoantibody negative. Individuals who developed diabetes had reduced serum levels of succinic acid and phosphatidylcholine (PC) at birth, reduced levels of triglycerides and antioxidant ether phospholipids throughout the follow-up, and increased levels of proinflammatory lysoPCs several months before seroconversion to autoantibody positivity. The lipid changes were independent of HLA risk for T1D. 
The appearance of IAA and GADA was preceded by diminished ketoleucine and elevated glutamic acid. These investigators suggested that autoimmunity might thus be a relatively late response to the early metabolic disturbances. In addition, autoantibody-positive children had higher levels of odd-chain triglycerides and polyunsaturated fatty acid-containing phospholipids than autoantibody-negative children, which were independent of age at first autoantibody appearance (Pflueger et al. 2011). But children who developed autoantibodies by age $2 \mathrm{yr}$ had twofold-lower concentration of methionine compared with those who developed autoantibodies by age 8 yr or remained autoantibody negative. They concluded that methionine is a potentially relevant amino acid for developing islet autoantibodies in early infancy. Interestingly, methionine is involved in DNA methylation, an epigenetic effect putatively involved in autoimmunity (Rakyan et al. 2011).

Recently Sherry et al. (2011) reported results of the Protégé trial of teplizumab in patients with new-onset T1D that used a composite end point that evaluated the proportion of subjects with a hemoglobin A1c $<6.5 \%$ and who used $<0.5 \mathrm{U} / \mathrm{kg} / \mathrm{d}$ of insulin. Although this trial did show significant improvement overall in C-peptide responses in subjects who received the full dose of teplizumab compared with placebo, a significant difference in the composite end point was not seen. Nonetheless, the rates of very low levels of insulin usage were greater in drug-treated subjects. Similar effects of successful immune therapies (based on C-peptide responses) have been reported on the need for exogenous insulin (Keymeulen et al. 2005).

With a similar strategy, Mortensen et al. have proposed a measure of "insulin-adjusted hemoglobin Alc (IAAlc)," which = HgbAlc $+4^{*}$ insulin does $(\mathrm{U} / \mathrm{kg} / \mathrm{d})$. Values of $<9$ were shown to identify individuals with a stimulated C-peptide level of at least $0.3 \mathrm{pmol} / \mathrm{mL}$, which has been associated with the clinical remission or "honeymoon" that is frequently seen after initial metabolic stabilization of new-onset T1D (Mortensen et al. 2009). This measurement has not been tested as an end point in clinical trials but may provide a clinically rele- vant measure of metabolic response that correlates with insulin secretion.

\section{$\beta$-Cell Visualization and Measurement of Pancreatic Mass}

It is important to note that metabolic studies evaluate $\beta$-cell function and not mass. Studies of the pathogenesis and response to immune therapy in nonobese diabetic (NOD) mice have shown that function may be compromised in settings of hyperglycemia (Sherry et al. 2006). Degranulated $\beta$ cells may recover function with immune therapy and the "honeymoon" of new-onset disease after the initial metabolic stabilization is likely to reflect recovery of dysfunctional cells. Newer approaches to imaging $\beta$-cell mass are in development. The ability to noninvasively image the pancreatic islets (Table 3), especially the quantification of insulin-producing $\beta$ cells in vivo, could provide a predictive biomarker for the development of T1D and additionally to monitor therapeutic interventions. However, the challenges associated with islet imaging owe to its small size (diameter $=100-400 \mu \mathrm{m}$ ), the islet density and the lack of the inherent contrast from the surrounding exocrine pancreas. Furthermore, pancreatic islets are dispersed throughout the pancreas and constitute only $2 \%-3 \%$ of the pancreatic volume (Wang et al. 2011).

Table 3. Potential modalities for islet imaging

Magnetic resonance imaging
Relaxation agents:
Gadolinium
Lanthanides
Manganese
Paramagnetic particles:
Superparamagnetic iron oxide (SPIO)
Positron emission tomography
Antibodies:
Beta cell surface proteins (IC2)
Cell receptors/transporters (DTBZ, GLP-1)
Optical imaging
Bioluminescence:
Luciferase
Green fluorescent protein (GFP)


Metabolic Biomarkers of $\beta$-Cell Destruction

\section{Nuclear Imaging}

Because of their relative high sensitivity, positron emission tomography (PET) and single-photon emission computed tomography (SPECT) are attractive approaches to allow targeted imaging of islets in vivo. It relies on radionuclide-labeled contrast agents like cell-specific antigens, receptors, metabolites, or pharmacologic agents that target $\beta$ cells. A monoclonal antibody-targeting $\beta$-cell-specific surface antigen (IC2) was used to estimate $\beta$-cell mass in vivo in a diabetic mouse model. Also single-chain antibodies (SCAs) were developed, which reportedly reduce the nonspecific binding to $\beta$ cells by removal of the Fc potion (Hampe et al. 2005; Ueberberg et al. 2009). Among these, visualization of the ligand of the vesicular monoamine transporter type 2 (VMAT2), labeled dihydrotetrabenazine (DTBZ), has been used in biobreeding/Worcester $(\mathrm{BB} / \mathrm{W})$ rats and patients with diabetes (Fig. 2 ) and has recently been suggested to be one of the more specific biomarkers for imaging $\beta$-cell mass. VMAT2 was found to be expressed by $\beta$ cells by an array study and confirmed by poly- merase chain reaction (PCR) (Maffei et al. 2004; Souza et al. 2006). The exocrine or other endocrine cells in the pancreas do not express VMAT2. A ligand for VMAT2 (DTBZ), frequently used for imaging of the pancreas, was used to identify a decline in $\beta$-cell mass in $\mathrm{BB} /$ $\mathrm{W}$ rats with diabetes and in patients without detectable C-peptide (Fig. 2). However, the signal in the C-peptide-deficient patients was not absent, which could be attributable to nonspecific binding to pancreatic exocrine tissue. The glucagonlike peptide-1 (GLP-1) receptor could be used as a target. It is triggered after binding of the agonists Exendin-3 and Exendin-4, and a correlation of Exendin- 3 uptake and $\beta$-cell mass in linear manner in diabetic rats visualized by SPECT has been shown (Eng et al. 1992; Brom et al. 2010; Pattou et al. 2010).

\section{MR Imaging}

Magnetic resonance imaging (MRI) offers the highest resolution images in vivo and soft tissue contrast, but has a low sensitivity. One potential way to approach this challenge is to use known

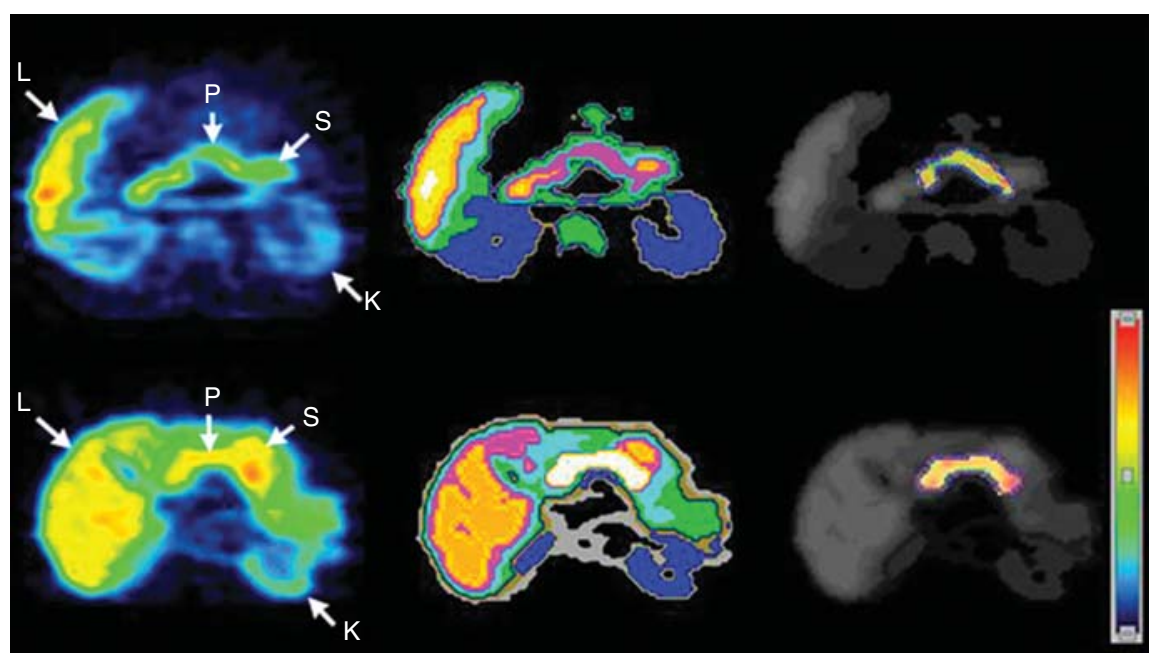

Figure 2. Transverse ${ }^{11} \mathrm{C}$-dihydrotetrabenazine PET images of patients (top row) and controls (bottom row). Summed dynamic PET images were obtained 0-90 min after injection of $\sim 481-555 \mathrm{MBq}$ of ${ }^{11}$ Cdihydrotetrabenazine (left). Corresponding tissue segmentation images are also shown (middle), with different colors being used to represent different organs. Voxelwise parametric images of VMAT2 binding potential (BPND) are shown (right) using another color scale (right bottom). These BPND images are fused onto a segmentation image using gray scale, with the pancreatic region of interest (ROI) boundary shown using dotted blue outlines (right). Abbreviations: L, liver; K, kidney; S, stomach; P, pancreas (Goland et al. 2009). 
contrast agents such as superparamagnetic ironoxide (SPIO) nanoparticles, paramagnetic gadolinium-based agents for negative (hypointense) and positive (hyperintense) contrast MRI, respectively. Human islets labeled with FDA-approved iron oxide ( ferumoxides) and transplanted into the liver appeared as hypointense foci representing single islets and/or islet cluster (Wang et al. 2011). In the first study, 2008 superparamagnetic iron-oxide nanoparticles labeled islets were transplanted into patients with T1D (Toso et al. 2008). The iron-loaded islets could be identified, but the number of transplanted islets did not correlate with the number of hypointense dots in the images and the variation of the number of dots during the study could not make conclusions about the graft outcomes. Another interesting approach to monitor the $\beta$-cell function is the accumulation of manganese $\mathrm{Mn}^{2+}$ in the pancreas after glucose infusion.

\section{Optical Imaging}

Islet-specific imaging has been achieved with the creation of transgenic animals expressing genetic reporters. For this imaging model, islets are transfected with the luciferase gene before transplantation, and the islets are imaged by bioluminescence. The signal is therefore proportional to $\beta$-cell mass, which was shown in the setting of increased and decreased $\beta$-cell mass conditions and after islet transplantation. In a similar approach, green fluorescent protein (GFP) -based bioluminescent imaging aids in isolation of pancreatic islets and studies of $\beta$ cell development, physiology, and blood flow.

\section{IDENTIFICATION OF ISLET INFLAMMATION AND $\beta$-CELL DEATH}

Identification of islet inflammation would be useful to guide the timing and therapeutic approaches for preservation of $\beta$-cell function. Gaglia et al. (2011) have used ferumoxtran-10 nanoparticles to identify islet inflammation. These magnetic nanoparticles can be used to identify leakage from the islet microvascular by MRI in areas of inflammation. Differences were identified between patients with new-onset T1D and healthy control subjects (Gaglia et al. 2011).
Lastly, none of the available methods have directly measured $\beta$-cell death, the primary pathologic event leading to disease and by which immune and other therapies can be judged. Berney et al. (2006) found an increase in insulin mRNA in the peripheral blood in patients after human islets transplantation with an adverse event in graft function. However, insulin mRNA is also based on $\beta$-cell function. Recently, Akirav et al. (2011) described a method for detection of $\beta$-cell-specific (i.e., demethylated) insulin DNA that is released from dying $\beta$ cells with a nested PCR reaction (Akirav et al. 2011). They show that it can be used to detect $\beta$ cell death following streptozotocin treatment of mice or in the NOD model, and higher levels of the demethylated insulin DNA are found in the bloodstream of patients with recent-onset T1D. Ongoing studies are evaluating the utility of this assay in distinguishing individuals at risk for disease who do and do not progress.

\section{CONCLUSION}

Markers that can identify the immune and metabolic progression of T1D are essential tools for the development of immune therapies for treatment and prevention of the disease. The lack of these markers has significantly impaired progress in the field because clinical trials that are now designed rely on metabolic end points that can only be evaluated at least 1 year or longer after onset or after presentation with diabetic glucose tolerance tests. Certain immunologic assays including autoantibodies and T-cell assays can distinguish responses in T1D patients from healthy control subjects and they may also identify individuals at the highest risk for progression from prediabetes to overt disease. Interestingly, combinations of tests, and even multiple antigen reactivities either by autoantibodies or $\mathrm{T}$ cells appears to identify the highest risk for disease progression and differentiates responses from healthy control subjects. Some assays are limited in application to individuals with particular genotypes that permit evaluation of antigen-specific responses and there is relatively little information on changes in these assays in clinical settings. Data on their 
performance in clinical trials in which the disease is modified will shed light on their significance as markers of the disease process. Finally, metabolic studies remain the standard end point for clinical trials. These studies, however, measure function and not $\beta$-cell mass or death, which are the primary targets of immune and other therapies. Further refinements in assays that can directly evaluate $\beta$ cells in combination with detection of immunologic effectors are likely to represent a package of mechanistic studies that will add significantly to our understanding of treatments to come.

\section{ACKNOWLEDGMENTS}

NIH R01 DK057846, U19-AI082713, RC4 DK 090805-01, JDRF grants 2007-502 and 20081012, and a gift from the Brehm Foundation and the Howalt family are gratefully acknowledged.

\section{REFERENCES}

Akirav EM, Lebastchi J, Galvan EM, Henegariu O, Akirav M, Ablamunits V, Lizardi PM, Herold KC. 2011. Detection of beta cell death in diabetes using differentially methylated circulating DNA. Proc Natl Acad Sci 108: 19018-19023.

Arif S, Tree TI, Astill TP, Tremble JM, Bishop AJ, Dayan CM, Roep BO, Peakman M. 2004. Autoreactive T cell responses show proinflammatory polarization in diabetes but a regulatory phenotype in health. J Clin Invest 113: 451-463.

Arif S, Moore F, Marks K, Bouckenooghe T, Dayan CM, Planas R, Vives-Pi M, Powrie J, Tree T, Marchetti P, et al. 2011. Peripheral and islet interleukin-17 pathway activation characterizes human autoimmune diabetes and promotes cytokine-mediated $\beta$-cell death. Diabetes 60: $2112-2119$.

Atkinson MA, Maclaren NK. 1994. The pathogenesis of insulin-dependent diabetes mellitus. $N$ Engl J Med 331: $1428-1436$.

Berney T, Mamin A, James Shapiro AM, Ritz-Laser B, Brulhart MC, Toso C, Demuylder-Mischler S, Armanet M, Baertschiger R, Wojtusciszyn A, et al. 2006. Detection of insulin mRNA in the peripheral blood after human islet transplantion predicts deterioration of metabolic control. Am J Transplant 6: 1704-1711.

Bougneres PF, Carel JC, Castano L, Boitard C, Gardin JP, Landais P, Hors J, Mihatsch MJ, Paillard M, Chaussain JL, et al. 1988. Factors associated with early remission of type I diabetes in children treated with cyclosporine. $N$ Engl J Med 318: 663-670.

Brom M, Andralojc K, Oyen WJ, Boerman OC, Gotthardt M. 2010. Development of radiotracers for the determi- nation of the $\beta$-cell mass in vivo. Curr Pharm Des 16: 1561-1567.

Brooks-Worrell B, Gersuk VH, Greenbaum C, Palmer JP. 2001. Intermolecular antigen spreading occurs during the preclinical period of human type 1 diabetes. J Immunol 166: 5265-5270.

Cambridge G, Leandro MJ, Teodorescu M, Manson J, Rahman A, Isenberg DA, Edwards JC. 2006. B cell depletion therapy in systemic lupus erythematosus: Effect on autoantibody and antimicrobial antibody profiles. Arthritis Rheum 54: 3612-3622.

Cernea S, Herold KC. 2010. Monitoring of antigen-specific CD8 T cells in patients with type 1 diabetes treated with antiCD3 monoclonal antibodies. Clin Immunol 134: $121-129$.

Coppieters KT, Roep BO, von Herrath MG. 2011. $\beta$ cells under attack: Toward a better understanding of type 1 diabetes immunopathology. Semin Immunopathol 33: $1-7$.

Dosch H, Cheung RK, Karges W, Pietropaolo M, Becker DJ. 1999. Persistent T cell anergy in human type 1 diabetes. J Immunol 163: 6933-6940.

Eng J, Kleinman WA, Singh L, Singh G, Raufman JP. 1992. Isolation and characterization of exendin-4, an exendin-3 analogue, from Heloderma suspectum venom. Further evidence for an exendin receptor on dispersed acini from guinea pig pancreas. J Biol Chem 267: 7402-7405.

Gaglia JL, Guimaraes AR, Harisinghani M, Turvey SE, Jackson R, Benoist C, Mathis D, Weissleder R. 2011. Noninvasive imaging of pancreatic islet inflammation in type 1A diabetes patients. J Clin Invest 121: 442-445.

Goland R, Freeby M, Parsey R, Saisho Y, Kumar D, Simpson N, Hirsch J, Prince M, Maffei A, Mann JJ, et al. 2009. 11CDihydrotetrabenazine PET of the pancreas in subjects with long-standing type 1 diabetes and in healthy controls. J Nucl Med 50: 382-389.

Greenbaum C, Seidel K, Pihoker C. 2004. The case for intravenous arginine stimulation in lieu of mixed-meal tolerance tests as outcome measure for intervention studies in recent-onset type 1 diabetes. Diabetes Care 27: 1202 1204.

Greenbaum C, et al. 2012. Biphasic fall in C-peptide over first two years from diagnosis: Composite TrilaNet data. Diabetes (in press).

Hampe CS, Wallen AR, Schlosser M, Ziegler M, Sweet IR. 2005. Quantitative evaluation of a monoclonal antibody and its fragment as potential markers for pancreatic $\beta$ cell mass. Exp Clin Endocrinol Diabetes 113: 381-387.

Hanifi-Moghaddam P, Schloot NC, Kappler S, Seissler J, Kolb H. 2003. An association of autoantibody status and serum cytokine levels in type 1 diabetes. Diabetes 52: $1137-1142$.

Herold KC, Hagopian W, Auger JA, Poumian-Ruiz E, Taylor L, Donaldson D, Gitelman SE, Harlan DM, Xu D, Zivin RA, et al. 2002. Anti-CD3 monoclonal antibody in newonset type 1 diabetes mellitus. N Engl J Med 346: $1692-$ 1698.

Herold KC, Brooks-Worrell B, Palmer J, Dosch HM, Peakman M, Gottlieb P, Reijonen H, Arif S, Spain LM, Thompson C, et al. 2009. Validity and reproducibility of measurement of islet autoreactivity by T-cell assays 
J. Lebastchi and K.C. Herold

in subjects with early type 1 diabetes. Diabetes 58: 2588-2595.

Herold KC, Pescovitz MD, McGee P, Krause-Steinrauf H, Spain LM, Bourcier K, Asare A, Liu Z, Lachin JM, Dosch HM. 2011. Increased T cell proliferative responses to islet antigens identify clinical responders to anti-CD20 monoclonal antibody (rituximab) therapy in type 1 diabetes. J Immunol 187: 1998-2005.

Huang H, Benoist C, Mathis D. 2010. Rituximab specifically depletes short-lived autoreactive plasma cells in a mouse model of inflammatory arthritis. Proc Natl Acad Sci 107: 4658-4663.

Karvonen M, Tuomilehto J, Libman I, LaPorte R. 1993. A review of the recent epidemiological data on the worldwide incidence of type 1 (insulin-dependent) diabetes mellitus. World Health Organization DIAMOND Project Group. Diabetologia 36: 883-892.

Keymeulen B, Vandemeulebroucke E, Ziegler AG, Mathieu C, Kaufman L, Hale G, Gorus F, Goldman M, Walter M, Candon S, et al. 2005. Insulin needs after CD3-antibody therapy in new-onset type 1 diabetes. $N$ Engl J Med 352: 2598-2608.

Krischer JP, Cuthbertson DD, Yu L, Orban T, Maclaren N, Jackson R, Winter WE, Schatz DA, Palmer JP, Eisenbarth GS. 2003. Screening strategies for the identification of multiple antibody-positive relatives of individuals with type 1 diabetes. J Clin Endocrinol Metab 88: 103-108.

Maffei A, Liu Z, Witkowski P, Moschella F, Del Pozzo G, Liu E, Herold K, Winchester RJ, Hardy MA, Harris PE. 2004. Identification of tissue-restricted transcripts in human islets. Endocrinology 145: 4513-4521.

Mortensen HB, Hougaard P, Swift P, Hansen L, Holl RW, Hoey H, Bjoerndalen $\mathrm{H}$, de Beaufort C, Chiarelli F, Danne T, et al. 2009. New definition for the partial remission period in children and adolescents with type 1 diabetes. Diabetes Care 32: 1384-1390.

Orban T, Sosenko JM, Cuthbertson D, Krischer JP, Skyler JS, Jackson R, Yu L, Palmer JP, Schatz D, Eisenbarth G. 2009. Pancreatic islet autoantibodies as predictors of type 1 diabetes in the Diabetes Prevention Trial-Type 1. Diabetes Care 32: 2269-2274.

Oresic M, Simell S, Sysi-Aho M, Nanto-Salonen K, Seppanen-Laakso T, Parikka V, Katajamaa M, Hekkala A, Mattila I, Keskinen P, et al. 2008. Dysregulation of lipid and amino acid metabolism precedes islet autoimmunity in children who later progress to type 1 diabetes. J Exp Med 205: 2975-2984.

Ouyang Q, Standifer NE, Qin H, Gottlieb P, Verchere CB, Nepom GT, Tan R, Panagiotopoulos C. 2006. Recognition of HLA class I-restricted $\beta$-cell epitopes in type 1 diabetes. Diabetes 55: 3068-3074.

Palmer JP, Fleming GA, Greenbaum CJ, Herold KC, Jansa LD, Kolb H, Lachin JM, Polonsky KS, Pozzilli P, Skyler JS, et al. 2004. C-peptide is the appropriate outcome measure for type 1 diabetes clinical trials to preserve $\beta$-cell function: Report of an ADA workshop, 21-22 October 2001. Diabetes 53: 250-264.

Pattou F, Kerr-Conte J, Wild D. 2010. GLP-1-receptor scanning for imaging of human $\beta$ cells transplanted in muscle. N Engl J Med 363: 1289-1290.

Pflueger M, Seppanen-Laakso T, Suortti T, Hyotylainen T, Achenbach P, Bonifacio E, Oresic M, Ziegler AG. 2011.
Age- and islet autoimmunity-associated differences in amino acid and lipid metabolites in children at risk for type 1 diabetes. Diabetes 60: 2740-2747.

Pinkse GG, Tysma OH, Bergen CA, Kester MG, Ossendorp F, van Veelen PA, Keymeulen B, Pipeleers D, Drijfhout JW, Roep BO. 2005. Autoreactive CD8 T cells associated with $\beta$ cell destruction in type 1 diabetes. Proc Natl Acad Sci 102: $18425-18430$.

Rakyan VK, Down TA, Balding DJ, Beck S. 2011. Epigenome-wide association studies for common human diseases. Nat Rev Genet 12: 529-541.

Seyfert-Margolis V, Gisler TD, Asare AL, Wang RS, Dosch HM, Brooks-Worrell B, Eisenbarth GS, Palmer JP, Greenbaum CJ, Gitelman SE, et al. 2006. Analysis of Tcell assays to measure autoimmune responses in subjects with type 1 diabetes: Results of a blinded controlled study. Diabetes 55: 2588-2594.

Sherry NA, Kushner JA, Glandt M, Kitamura T, Brillantes AM, Herold KC. 2006. Effects of autoimmunity and immune therapy on $\beta$-cell turnover in type 1 diabetes. $\mathrm{Di}$ abetes 55: 3238-3245.

Sherry N, Hagopian W, Ludvigsson J, Jain SM, Wahlen J, Ferry RJ Jr, Bode B, Aronoff S, Holland C, Carlin D, et al. 2011. Teplizumab for treatment of type 1 diabetes (Protege study): 1-year results from a randomised, placebocontrolled trial. Lancet 378: 487-497.

Sosenko JM, Palmer JP, Greenbaum CJ, Mahon J, Cowie C, Krischer JP, Chase HP, White NH, Buckingham B, Herold $\mathrm{KC}$, et al. 2006. Patterns of metabolic progression to type 1 diabetes in the Diabetes Prevention Trial-Type 1. Diabetes Care 29: 643-649.

Sosenko JM, Palmer JP, Rafkin-Mervis L, Krischer JP, Cuthbertson D, Matheson D, Skyler JS. 2008. Glucose and Cpeptide changes in the perionset period of type 1 diabetes in the Diabetes Prevention Trial-Type 1. Diabetes Care 31: 2188-2192.

Souza F, Simpson N, Raffo A, Saxena C, Maffei A, Hardy M, Kilbourn M, Goland R, Leibel R, Mann JJ, et al. 2006. Longitudinal noninvasive PET-based $\beta$ cell mass estimates in a spontaneous diabetes rat model. J Clin Invest 116: $1506-1513$.

Standifer NE, Ouyang Q, Panagiotopoulos C, Verchere CB, Tan R, Greenbaum CJ, Pihoker C, Nepom GT. 2006. Identification of Novel HLA-A*0201-restricted epitopes in recent-onset type 1 diabetic subjects and antibodypositive relatives. Diabetes 55: 3061-3067.

Steele C, Hagopian WA, Gitelman S, Masharani U, Cavaghan M, Rother KI, Donaldson D, Harlan DM, Bluestone J, Herold KC. 2004. Insulin secretion in type 1 diabetes. Diabetes 53: 426-433.

Stiller CR, Dupre J, Gent M, Jenner MR, Keown PA, Laupacis A, Martell R, Rodger NW, von Graffenried B, Wolfe BM. 1984. Effects of cyclosporine immunosuppression in insulin-dependent diabetes mellitus of recent onset. Science 223: $1362-1367$.

Takahashi K, Ohara M, Sasai T, Homma H, Nagasawa K, Takahashi T, Yamashina M, Ishii M, Fujiwara F, Kajiwara T, et al. 2011. Serum CXCL1 concentrations are elevated in type 1 diabetes mellitus, possibly reflecting activity of anti-islet autoimmune activity. Diabetes Metab Res Rev 27: $830-833$. 
Toso C, Vallee JP, Morel P, Ris F, Demuylder-Mischler S, Lepetit-Coiffe M, Marangon N, Saudek F, James Shapiro AM, Bosco D, et al. 2008. Clinical magnetic resonance imaging of pancreatic islet grafts after iron nanoparticle labeling. Am J Transplant 8: 701-706.

Tsai EB, Sherry NA, Palmer JP, Herold KC. 2006. The rise and fall of insulin secretion in type 1 diabetes mellitus. Diabetologia 49: 261-270.

Ueberberg S, Meier JJ, Waengler C, Schechinger W, Dietrich JW, Tannapfel A, Schmitz I, Schirrmacher R, Koller M, Klein HH, et al. 2009. Generation of novel single-chain antibodies by phage-display technology to direct imaging agents highly selective to pancreatic $\beta$ - or $\alpha$-cells in vivo. Diabetes 58: 2324-2334.

Velthuis JH, Unger WW, Abreu JR, Duinkerken G, Franken K, Peakman M, Bakker AH, Reker-Hadrup S, Keymeulen
Metabolic Biomarkers of $\beta$-Cell Destruction

B, Drijfhout JW, et al. 2010. Simultaneous detection of circulating autoreactive $\mathrm{CD} 8^{+}$T-cells specific for different islet cell-associated epitopes using combinatorial MHC multimers. Diabetes 59: 1721-1730.

Wang P, Medarova Z, Moore A. 2011. Molecular imaging: A promising tool to monitor islet transplantation. J Transplant 2011: 202915.

Yu L, Herold K, Krause-Steinrauf H, McGee PL, Bundy B, Pugliese A, Krischer J, Eisenbarth GS. 2011. Rituximab selectively suppresses specific islet antibodies. Diabetes 60: $2560-2565$.

Zak KP, Popova VV, Mel'nichenko SV, Tron'ko EN, Man'kovskii BN. 2010. The level of circulating cytokines and chemokines in the preclinical and early clinical stages of type IA diabetes mellitus development. Ter Arkh 82: 10-15. 




\title{
Immunologic and Metabolic Biomarkers of $\beta$-Cell Destruction in the Diagnosis of Type 1 Diabetes
}

\author{
Jasmin Lebastchi and Kevan C. Herold
}

Cold Spring Harb Perspect Med 2012; doi: 10.1101/cshperspect.a007708 originally published online April 25, 2012

\section{Subject Collection Type I Diabetes}

The Pathogenesis and Natural History of Type 1

Diabetes

Mark A. Atkinson

Do MHCII-Presented Neoantigens Drive Type 1 Diabetes and Other Autoimmune Diseases? Philippa Marrack and John W. Kappler

Clinical Immunologic Interventions for the Treatment of Type 1 Diabetes Lucienne Chatenoud, Katharina Warncke and Anette-G. Ziegler

Update on Islet Transplantation Michael McCall and A.M. James Shapiro

Immunologic and Metabolic Biomarkers of $\beta$-Cell Destruction in the Diagnosis of Type 1 Diabetes Jasmin Lebastchi and Kevan C. Herold

Advancing Animal Models of Human Type 1 Diabetes by Engraftment of Functional Human

Tissues in Immunodeficient Mice Michael A. Brehm, Alvin C. Powers, Leonard D. Shultz, et al.

Breakdown in Peripheral Tolerance in Type 1 Diabetes in Mice and Humans Lukas T. Jeker, Hélène Bour-Jordan and Jeffrey $A$. Bluestone

Antigen-Specific Therapeutic Approaches in Type 1 Diabetes Xavier Clemente-Casares, Sue Tsai, Carol Huang, et al.
Humoral Autoimmunity in Type 1 Diabetes:

Prediction, Significance, and Detection of Distinct Disease Subtypes

Massimo Pietropaolo, Roberto Towns and George S. Eisenbarth

Endoplasmic Reticulum Stress, Pancreatic $\beta$-Cell Degeneration, and Diabetes Feroz R. Papa

Islet Autoantigens: Structure, Function, Localization, and Regulation Peter Arvan, Massimo Pietropaolo, David Ostrov, et al.

Environmental Triggers of Type 1 Diabetes Mikael Knip and Olli Simell

Generating $\beta$ Cells from Stem Cells--The Story So Far Matthias Hebrok

Antigen Targets of Type 1 Diabetes Autoimmunity Bart O. Roep and Mark Peakman

Connecting Type 1 and Type 2 Diabetes through Innate Immunity Justin I. Odegaard and Ajay Chawla

The Hygiene Hypothesis: An Explanation for the Increased Frequency of Insulin-Dependent Diabetes Jean-François Bach and Lucienne Chatenoud

For additional articles in this collection, see http://perspectivesinmedicine.cshlp.org/cgi/collection/ 